\title{
PREDICTING THE LEVEL OF BANKS' CUSTOMER FORGIVENESS FOLLOWING A BANKING CRISIS
}

Fridrik Eysteinsson, School of Business, University of Iceland, Reykjavik, Iceland Thorhallur Gudlaugsson, School of Business, University of Iceland, Reykjavik, Iceland

dx.doi.org/10.18374/RBR-13-2.12

\begin{abstract}
In October 2008 three of the biggest banks in Iceland collapsed along with the biggest savings and loans. Many of their customers were directly harmed as a consequence. The level of customer forgiveness was low. This paper deals with the research questions, "Which factors predict the level of banks' customer forgiveness following a banking crisis?" and "Which factor is the most important in predicting the level of banks' customer forgiveness following a banking crisis? The methodology is quantitative, in the form of a survey. The population of interest was customers of the Icelandic banks. The findings show that six factors explain $78.5 \%$ of the variability in forgiveness. The factor that is most important in predicting the level of banks' customer forgiveness is how well they thought they could rely on the banks to meet their expectations.
\end{abstract}

Keywords: Customer forgiveness; Regression analysis; Banks; Banking crisis 